\title{
An Early Warning System on the Propensity of Survival and Failure of Non-life Insurance Firms in the Philippines (2002-2011)
}

\author{
Eduardo T. Torno ${ }^{\mathrm{a}}$ and Prof. Tomas S. Tiu ${ }^{\mathrm{b}}$ \\ ${ }^{a k b}$ The Graduate School, University of Santo Tomas Espana Street, Manila 1015, Philippines
}

\begin{abstract}
This study examines the factors affecting survival and failure of non-life insurance firms in the Philippines and classifies the survivability of the firms into strong, moderate, weak and insolvent firms. Selected insolvency indicators are represented by the variables most commonly found and validated in insurance literature. The study used a 10-year panel data of 79 non-life insurance firms in the Philippines from year 2002 to 2011 Annual Statements (AS) reported at the Philippine Insurance Commission (IC). The variables of the study were tested using Levene-Welch-Games-Howell and logit regression. The result shows that firm size, natural catastrophe due to typhoon and flood, ownership, leverage, degree of diversification, growth of equity and paid-up capital compliance are significant factors that affect the survivability of non-life insurance firms in the Philippines. The result of the study serves as a useful tool for the regulator and stakeholders involved in the industry.
\end{abstract}

Keywords: non-life insurance, survival, failure, early warning, Levene-Welch-Games-Howell, logit regression

\section{Introduction}

Insurance plays an important role in developing countries such as the Philippines. This sector holds a tremendous amount of business transactions and employed huge number of people (Simpson and Damoah, 2009). It also provides capital to other industries as they play a role of financial intermediaries (Atkins and Bates, 2008). Hence, the government has the responsibility in monitoring the financial solvency position of insurance companies. Insurance solvency entails enough resources needed to honor its contractual obligation to the insured according to what is written on the insurance policy. When an insurer becomes insolvent or financially impaired, state regulators must take appropriate actions such as license revocation, cease-and-desist orders, and other actions that restrict an insurer's freedom to do business (Rajda, 2011). The idea of evaluating solvency position of insurance companies pave the way to the main theme of this research as the propensity of survival and failure is inevitable in non-life insurance firms (Pitselis, 2008). In the Philippines, there are 110 non-life insurance companies in 2002, however in the year 2012 the non-life insurance companies were reduced to 81 firms. In this paper, the researcher posited three objectives. First, to determine which variables that affects the survival and failure of non-life insurance firms in the Philippines. Secondly, to compare the effects of significant variables which according to their survivability index (strong, moderate, weak and insolvent) of nonlife insurance firms. And third, to provide an early warning system on the probability of survival and failure which classify non-life insurance firms into survived (strong) and failed (moderate, weak and insolvent).

\section{Literature/Theoretical underpinning}

Based on the resource-based theory of the firm, the firm's probability of survival depends on their internal characteristics and resources. From these resources they develop distinct capabilities to generate competitive advantage and adapt in market conditions (Pérez and Castillejo, 2008). Consequently, the theory of public interest stated that the regulators impose the regulatory framework in a way to prevent the market failure (Domas, 2003). As these theories applied to the non-life insurance business, firms depend to their internal capabilities in doing their underwriting and investing activities while embracing the extreme influence of the regulatory environment. The following are the variables and hypotheses formulated for the purpose of this study.

\subsection{Firm-Specific Variables}

Firm size was found to be negatively related to the insolvency propensity in most insurance literature. The larger the firm size, the higher the probability to survive (Kleffner and Lee, 2009; Leadbetter and Dibra, 2008; Sanchis, Segovia, Gil, Heras and Vilar, 2007; Joo, 2013; Rameshchandra, 2013; Stölzle, Koissi and Shapiro, 2010; Chen and Wong, 2004; Pottier and Sommer, 2011). Profitability is often to be found a predictor of insolvency. Insurers that attained higher profitability level are expected to have lower insolvency risk (Stölzle, Koissi and Shapiro, 2010; Sharpe and Stadnik, 2007; Kleffner and Lee, 2009; Cheng-Ping, 2006). According to the study of Kleffner and Lee (2009), Leadbetter and Dibra, (2008), and Chen and Wong (2004) a substantial increase in net premium growth will cause a higher probability of insolvency. Claims ratio is a 
measure of the performance of an insurance company. This ratio is one of the predictor of insolvency and significantly affects the solvency state of the insurers (Rameshchandra, 2013; Joo, 2013). Another important performance measure is the expense ratio. The lower the expense ratio indicates higher operation performance (Cheng-Ping, 2006). The combined ratio is one of the most common measures of underwriting profitability. The combined ratio is positively related to the propensity of insolvency (Browne and Hoyt, 1995; Cheng and Weiss, 2012; Joo, 2013). Leverage ratio represents a high level of potential liabilities relative to capital. The greater an insurer's capital relative to its liabilities, the better its ability to absorb unexpected shocks (Kleffner and Lee, 2009). Hence, leverage is positively related to the risk of insolvency. Capital growth is calculated as one-year rate of change in capital and surplus. Kleffner and Lee (2009) stated that the capital growth is changes in an insurer's ability to absorb unexpected losses. Therefore, growth of equity is negatively related to insolvency propensity. There are two types of ownership most commonly found in the non-life insurance companies in the Philippines: domestic and foreign companies. Since the majority of non-life insurance firms in the Philippines are domestically-owned, therefore these firms suffer more failure than foreign companies. Investment performance discloses the effectiveness and efficiency of investment decisions (Joo, 2013). According to Stölzle, Koissi and Shapiro (2010), the financial strength of the company is affected by its investment performance. Therefore, investment performance is negatively correlated to insolvency rate (Kim, Anderson, Amburgey and Hickman, 1995). Based on the study of Pottier and Sommer (2011) the gross expenses and commissions/gross premium written have positive influence to the insolvency risk in examining the value of the group-level from which the insurer is affiliated. Thus, the higher the ratio of operating expenses to premium growth, the higher the probability of non-life insurance firms to fail. In view of these arguments where the firmspecific variables relate to survival and failure of non-life insurance firms, the researcher hypothesizes that:

Hypothesis 1: Firm-specific variables are positively related to the survival (failure) of non-life insurance firms.

\subsection{Degree of Diversification}

The degree of diversification was measured by Herfindahl-Hirschman Index (HHI). According to the study of Cheng and Weiss (2012), the industry Herfindahl-Hirschman Index (HHI) is useful in identifying the financially distressed insurer because it indicates the distribution of premium across insurers in the industry. Also, the study of Stölzle, Koissi and Shapiro (2010) found that the line of business Herfindahl-Hirschman Index (HHI) is positively related to financial strength. Therefore, the degree of diversification is positively related to insolvency of insurance firms. Hence, the researcher proposes the hypothesis that:

Hypothesis 2: The degree of diversification measured by Herfindahl-Hirschman Index (HHI) is positively related to the survival (failure) of non-life insurance firms.

\subsection{Natural Catastrophe Exposure}

Due to the changes in the nature of risk of insurance industry, Cheng and Weiss (2012) tested the effects of hurricane exposure in predicting insolvency of insurance firms. They tested the variable related to the hurricane prone areas. The result of the study showed that hurricane exposure was significantly related to insurance insolvency. In the Philippines there are two most common disasters that occurred every year, these are typhoons and floods. Thus, the researcher posits the hypothesis that:

Hypothesis 3: Natural catastrophe is positively related to the survival (failure) of non-life insurance firms.

\subsection{Regulatory framework}

Those non-life insurance firms unable to comply with the minimum paid-up capitalization requirement will be subject to regulatory sanctions. In connection with the Department Order 15-2012, non-life insurance companies in the Philippines are required to comply with the minimum paid-up capitalization amount. The regulatory compliance increases the chance of survival in non-life insurance firms. Hence, the researcher proposes the following hypothesis:

Hypothesis 4: Paid-up capitalization compliance is positively related to the survival (failure) of non-life insurance firms.

The hypothesized research model is shown in Figure 1. 


\subsection{Research Design}

\section{Methodology}

The use of descriptive-correlational technique was utilized in this paper to determine the relationship of independent and dependent variables in relation to the propensity of survival and failure of non-life insurance firms. This aids the researcher to identify statistically significant correlation among the identified endogenous and exogenous variables of the study.

\subsection{Data Collection and Sample Firms}

The subject of the study is the non-life insurance firms of the Philippines. Data were collected through a formal letter of request directly address to the Commissioner of Insurance Commission (IC). The samples includes non-life insurance firms authorized to operate by the Insurance Commission, non-life insurance firms with at least one year of operations and non-life insurance firms with complete data set from the period of 2002 to 2011. There were 110 non-life insurance firms from the sample period 2002-2011 but only 79 non-life insurance firms were included in this study. The 31 non-life insurance firms were removed due to incomplete data set.

\subsection{Measures}

Independent variables are represented by firm size (in natural logarithmic form), losses paid due to typhoon (in natural logarithmic form), losses paid due to flood (in natural logarithmic form), profitability ratio, premium growth ratio, claims ratio, expense ratio, combined ratio, leverage ratio, growth of equity ratio, investment performance ratio, operating expense to premium growth ratio, degree of diversification represented by Herfindahl-Hirshman Index (HHI), ownership (dummy variable; $1=$ domestic, $0=$ foreign), and capital compliance (dummy variable; $1=$ compliant, $0=$ non-compliant) obtained and computed based on the Annual Statements of 79 non-life insurance firms. The dependent variables are classified into (1) Strong (>150\% Capital adequacy ratio), (2) Moderate (120 - 149\% Capital Adequacy Ratio), (3) Weak (100 - 119\% Capital Adequacy Ratio), and (4) Insolvent (<100\% Capital Adequacy Ratio).

\subsection{Analytic Approach}

Data were analyzed by the combination of statistical techniques such as Levene's test of homogeneity of variances and equality of means, Welch test of equality corrected for the deficiencies found in the Levene's test and Games-Howell test is used to detect unequal variances in the characteristics (strong, moderate, weak and insolvent) of the non-life insurance firms. Logistic regression is used to determine the probability rate of survival and failure of non-life insurance firms using Statistical Package for the Social Sciences (SPSS) version 17.

\subsection{Assessment of Measurement Model}

\section{Results/Findings}

This study aims to know the susceptibility of survival and failure of non-life insurance firms in the Philippines. Thus, this study answers the following specific objectives to determine factors affecting survival and failure of non-life insurance firms.

1. To determine which determinants significantly affect the probability of survival and failure of non-life insurance firms.

First, the factors or determinants are described through descriptive statistics to detect potentials significant variables in the study (see Table 1). The mean, standard deviation and 95\% confidence interval for the mean reflects salient influence of the determinants to the survival and failure of the non-life insurance firms. Low standard deviation (within the $95 \%$ confidence interval) shows that the potential determinants that could describe survival and failure of non-life insurance firms are firm size, losses paid due to typhoon, losses paid due to flood, leverage, degree of diversification, and capital compliance. Second, a Levene-Welch-GamesHowell one-way analysis of variance (ANOVA) using multiple comparisons was done to determine significant determinants that describe strong, moderate, weak and insolvent non-life insurance firms. Descriptive statistics show that the non-life insurance firms are not equally distributed implying unequal variances in the sample. The Levene's test for the 790 total observations was applied to show proof that the significance level of Levene statistic is lesser $(<)$ than the $5 \%$ level. The result of homogeneity of variances indicates incidence of unequal variances and the Welch test of equality corrected for the deficiencies found in the Levene's test (see Table 2). The Welch test reveals that the survival and failure variation is high in the following factors: firm size, losses paid due to typhoon, losses paid due to flood, leverage, and degree of diversification. The capital compliance is a categorical or nominal variable that cannot be process (undefined) in Welch's test. The survival indicators vary from non-life companies at $5 \%$ level of significance (see Table 2). 
2. To compare the effects of firms size, payments to natural calamities (typhoon and flood), leverage, degree of diversification and capital compliance to survival or insolvency of non-life insurance firms.

Table 3 shows the multiple comparisons of determinants to survival indicators of non-life insurance firms. In the case of firm size, the study determines variation in survival (strong, moderate, weak and insolvent) of the 79 firms in 10 years. The results show that the strong firm has higher mean firm size than moderate, weak and insolvent firms at 5\% level of significance, respectively. Also, moderate non-life insurance firms have better mean firm size than weak and insolvent firms at 5\% level of significance, respectively. Mean losses paid due to typhoon is higher in strong, moderate and failed non-insurance firms and lower in weak non-life insurance firms at 5\% level of significance. Mean losses paid due to flood is higher in strong non-life firms than weak non-life firms at 5\% level of significance. Leverage differs also in the different survival indicators of the non-life insurance firms. Strong non-life insurance firms have higher mean leverage than weak and failed companies at $5 \%$ level of significance. The multiple comparisons test show that strong non-life insurance firms have higher mean degree of diversification than moderate, weak and failed firms at 5\% level of significance, respectively. Weak non-life insurance firms have higher mean degree of diversification than failed firms at $5 \%$ level of significance.

3. To provide an early warning system on the probability of survival and failure that will classify firms into survived (strong) and failed (moderate, weak and insolvent) non-life insurance firms.

Table 4 shows the results of the logit regression on survival of non-life insurance firms. The constant indicates that at the beginning of 2002 the chance of survival of an average non-life insurance firm is zero. Literal interpretation of the constant indicates that the chance of survival of a non-life insurance firm is zero assuming that firm size, capital compliance, leverage, and ownership are not known. A 1\% increase in firm size affects survival of the non-life insurance firms by $1.349 \%$ at $5 \%$ level of significance. Firm with high losses paid due to typhoon has a lower chance of survival. A $1 \%$ increases in leverage increase the chance of survival of non-life insurance firm. A $1 \%$ increases in growth of equity decrease the chance of survival of a non-life insurance firm. Foreign owned non-life insurance firms have a better chance of survival than the domestic owned companies. Test of the parameters are all significant at $5 \%$ level.

\subsection{Hypothesis Testing}

In the light of this study, the first alternative hypothesis posited by the researcher is to determine which firms-specific variables that affect the survival and failure of non-life insurance firms was significant and accepted in terms of firm size $(\beta=1.349$, sig. .000), leverage $(\beta=0.291$; sig. .000$)$, growth of equity $(\beta=-$ 0.951 ; sig. .000) and ownership ( $\beta=-0.650$; sig. .000) under the Levene-Welch-Games-Howell test and logit regression approach. The second alternative hypothesis is to determine the degree of diversification measured in terms of Herfindahl-Hirshman Index (HHI) affects the survival and failure of non-life insurance firms was found significant (sig. .000) and accepted in this study. The third alternative hypothesis is to determine the natural catastrophe in terms of exposure due to typhoon $(\beta=-0.036$; sig. .000) and flood (sig. .000) affects the survival and failure of non-life insurance firms was found significant and accepted in this study. The fourth alternative hypothesis proposed by the researcher is the regulatory framework represented by the paid-up capitalization compliance affects the survival and failure of non-life insurance firms was found significant (sig. .000) and accepted in this study.

\section{Discussion and Implications}

Based on the result of this study, the variables affecting survivability of non-life insurance firms are firm size, losses paid due to typhoon and flood, leverage, degree of diversification, growth of equity and capital compliance. The result of the study corroborates to other empirical studies that have founded that the firm size affects survival of the non-life insurance companies because larger insurers had a lower incidence of insolvency or failure (Kleffner and Lee, 2009; Pérez and Castillejo, 2008). Losses paid due to typhoon and floods are natural disaster affecting survival of non-life insurance firms. This implies that the effects of calamities such as typhoons and floods affect the survival of non-life insurance firms. This echoes the study conducted by Cheng and Weiss (2012) found that hurricane exposure affects the insurance insolvency. Payments for insurance due to loss of properties diminish the survival of underwriting firms. Kramaric (2012) showed that large insurance companies with total gross written premium have a higher leverage coefficient. Degree of diversification affects survival of non-life insurance companies because it indicates the distribution of premium across insurers in the insurance industry (Cheng and Weiss 2012). This implies the more diversified a non-life insurance company is, the higher its incidence of survival. Correspondingly, under the logit regression, the results implied that foreign non-life insurance firms have higher probability of survival than domestic non-life insurance firms. 


\section{Conclusions and Directions for Future Research}

Research in insurance insolvency is important field of study because it plays an important role in the risk management of the people and business. The importance of this industry contributes to the growth of economy. Thus, monitoring the insolvency of non-insurance firms protects the interest of the general public. This study revealed the importance of the variable that were found significant to survival and failure of non-life insurance firms in the Philippines. The use of 10 years of data along with use of several statistical tests to validate the results allows a robust use of inferences. The four hypothesis formulated in this study were all accepted. This study also filled the gap in insurance literature with the findings of the significant variables that were supported by the previous research. The result of the study will aid the insurance regulators in the decision making process for the effective promotion solvency standards of the industry and serves as an early warning system in evaluating and monitoring non-life insurance firm's insolvency status. This study was limited to the use of the variables related to the propensity of survival and failure of non-life insurance firms in the Philippine setting, the future direction of this study suggests exploring the effects of merger and acquisition among the non-life insurance firms in the Philippines. This study also suggests the use of the Risk-Based Capital (RBC) in against the effectives of paid-up capital compliance mandated by the Insurance Commission. Furthermore, exploring different method such as Neural Networks, Data Envelopment Analysis (DEA) and Stochastic Regression Analysis (SFA) to determine the likelihood of survival in the Philippine setting is an interesting part of future research in this field.

\section{References}

[1] Atkins, D., \& Bates, I. (2008). Insurance. London, U.K.: Global Professional Publishing.

[2] Berry-Stolzle, T. R., Koissi, M.-C., \& Shapiro, A. F. (2010). Detecting fuzzy relationships in regression models: The case of insurer solvency surveillance in Germany. Insurance: Mathematics and Economics , 46 (3), 554-567.

[3] Browne, M. J., \& Hoyt, R. E. (1995). Economic and market predictors of insolvencies in the property-liability insurance industry. Journal of Risk and Insurance , 62 (2), 309-327.

[4] Chen, R., \& Wong, K. A. (2004). The determinants of financial health of Asian insurance companies. Journal of Risk and Insurance , 71 (3), 469-499.

[5] Cheng-Ping, C. (2006). Establishing a performance prediction model for insurance companies. Journal of American Academy of Business , 8 (1), 73-77.

[6] Esteve-Pérez, S., \& Mañez-Castillejo, J. A. (2008). The resource-based theory of the firm and firm survival. Small Business Economics , 30 (3), 231-249.

[7] Hantke-Domas, M. (2003). The public interest theory of regulation: Non-existence or misinterpretation? European Journal of Law and Economics , 15 (2), 165-194

[8] Joo, B. (2013). Analysis of financial stability of Indian non-life insurance companies. Asian Journal of Finance \& Accounting , 5 (1), 306-319.

[9] Kim, Y.-D., Anderson, D. R., Amburgey, T. L., \& Hickman, J. C. (1995). The Use of event history analysis to examine insurer insolvencies. Journal of Risk and Insurance , 62 (1), 94-110.

[10] Kleffner, A. E., \& Lee, R. B. (2009). An examination of property \& casualty insurer solvency in Canada. Journal of Insurance Issues, 32 (1), 52-77.

[11] Kramaric, T. P. (2012). Predicting takeover targets: Case of Croatian insurance companies (1998-2010). Journal of Global Business Management , 8 (1), 33-41.

[12] Leadbetter, D., \& Dibra, S. (2008). Why insurers fail: The dynamics of property and casualty insurance insolvency in Canada. Geneva Papers on Risk \& Insurance, 33 (3), 464-488.

[13] Pitselis, G. (2008). An overview on solvency supervision, regulations and prediction of insolvency. Belgian Actuarial Bulletin , 3753.

[14] Pottier, S. W., \& Sommer, D. W. (2011). Empirical evidence on the value of group-level financial information in insurer solvency surveillance. Risk Management \& Insurance Review , 14 (1), 73-88.

[15] Rajda, G. E. (2011). Principles of Risk Management and Insurance (11th ed.). England: Pearson Education Limited.

[16] Rameshchandra, P. O. (2013). Solvency analysis: A study of public and private Insurance companies in India. Indian Journal of Applied Research , 3 (5), 1-4.

[17] Sanchis, A., Segovia, M., Gil,, J., Heras, A., \& Vilar, J. (2007). Rough Sets and the role of the monetary policy in financial stability (macroeconomic problem) and the prediction of insolvency in insurance sector (microeconomic problem). European Journal of Operational Research , 181 (3), 1554-1573.

[18] Sharpe, I. G., \& Stadnik, A. (2007). Financial distress in Australian general insurers. Journal of Risk and Insurance , 74 (2), 377399.

[19] Simpson, S., \& Damoah, O. (2009). An evaluation of financial health of non-life insurance companies of developing countries: The case of Ghana. ICFAI Journal Of Risk \& Insurance , 6 (1), 30-49. 
Tables and Figures

Table 1. Descriptive statistics for Survival and failure of non-life insurance companies

\begin{tabular}{|c|c|c|c|c|c|c|}
\hline & & $\mathrm{N}$ & Mean & $\begin{array}{l}\text { Std. } \\
\text { Dev. }\end{array}$ & $\begin{array}{c}95 \% \\
\text { Confidence } \\
\text { Interval for } \\
\text { Mean }\end{array}$ & \\
\hline Independent & Dependent & & & & Lower Bound & $\begin{array}{l}\text { Upper } \\
\text { Bound }\end{array}$ \\
\hline \multirow{5}{*}{ Firm Size (FRS) } & $1=$ strong & 280 & 20.65 & 1.09 & 20.52 & 20.78 \\
\hline & $2=$ moderate & 71 & 19.89 & 0.84 & 19.69 & 20.09 \\
\hline & $3=$ weak & 352 & 19.44 & 0.86 & 19.35 & 19.53 \\
\hline & $4=$ insolvent & 87 & 19.55 & 0.57 & 19.42 & 19.67 \\
\hline & Total & 790 & 19.92 & 1.08 & 19.85 & 20.00 \\
\hline \multirow{5}{*}{$\begin{array}{l}\text { Losses Paid Due to } \\
\text { Typhoon (TEX) }\end{array}$} & $1=$ strong & 280 & 6.61 & 7.29 & 5.75 & 7.46 \\
\hline & $2=$ moderate & 71 & 6.31 & 6.73 & 4.71 & 7.90 \\
\hline & $3=$ weak & 352 & 3.29 & 5.55 & 2.71 & 3.87 \\
\hline & $4=$ insolvent & 87 & 5.30 & 6.45 & 3.92 & 6.67 \\
\hline & Total & 790 & 4.96 & 6.59 & 4.50 & 5.42 \\
\hline \multirow{5}{*}{$\begin{array}{l}\text { Losses Paid Due to } \\
\text { Flood (FEX) }\end{array}$} & $1=$ strong & 280 & 6.10 & 6.96 & 5.28 & 6.92 \\
\hline & $2=$ moderate & 71 & 4.71 & 6.39 & 3.20 & 6.23 \\
\hline & $3=$ weak & 352 & 2.78 & 5.32 & 2.22 & 3.34 \\
\hline & $4=$ insolvent & 87 & 4.12 & 6.13 & 2.82 & 5.43 \\
\hline & Total & 790 & 4.28 & 6.30 & 3.84 & 4.72 \\
\hline \multirow[t]{5}{*}{ Profitability (PRO) } & $1=$ strong & 280 & 0.02 & 0.05 & 0.02 & 0.03 \\
\hline & $2=$ moderate & 71 & 0.02 & 0.04 & 0.01 & 0.03 \\
\hline & $3=$ weak & 352 & 0.02 & 0.04 & 0.01 & 0.02 \\
\hline & $4=$ insolvent & 87 & 0.02 & 0.03 & 0.01 & 0.02 \\
\hline & Total & 790 & 0.02 & 0.04 & 0.02 & 0.02 \\
\hline \multirow{5}{*}{$\begin{array}{l}\text { Premium Growth } \\
\text { (PRG) }\end{array}$} & $1=$ strong & 280 & 0.02 & 0.48 & -0.04 & 0.08 \\
\hline & $2=$ moderate & 71 & -0.06 & 1.20 & -0.34 & 0.23 \\
\hline & $3=$ weak & 352 & -1.51 & 28.13 & -4.45 & 1.44 \\
\hline & $4=$ insolvent & 87 & 0.06 & 0.26 & 0.00 & 0.11 \\
\hline & Total & 790 & -0.66 & 18.78 & -1.97 & 0.65 \\
\hline \multirow{5}{*}{ Claims Ratio (CLR) } & $1=$ strong & 280 & -0.40 & 14.15 & -2.06 & 1.27 \\
\hline & $2=$ moderate & 71 & 0.34 & 0.18 & 0.30 & 0.38 \\
\hline & $3=$ weak & 352 & 0.31 & 0.27 & 0.29 & 0.34 \\
\hline & $4=$ insolvent & 87 & 0.29 & 0.22 & 0.25 & 0.34 \\
\hline & Total & 790 & 0.06 & 8.42 & $\begin{array}{l}-0.53 \\
\end{array}$ & 0.65 \\
\hline \multirow[t]{5}{*}{ Expense Ratio (EXR) } & $1=$ strong & 280 & 0.27 & 13.37 & -1.30 & 1.84 \\
\hline & $2=$ moderate & 71 & 0.86 & 0.76 & 0.68 & 1.04 \\
\hline & $3=$ weak & 352 & 0.74 & 0.50 & 0.69 & 0.80 \\
\hline & $4=$ insolvent & 87 & 0.77 & 0.76 & 0.61 & 0.93 \\
\hline & Total & 790 & 0.59 & 7.97 & 0.03 & 1.15 \\
\hline \multirow[t]{5}{*}{ Combined Ratio (COR) } & $1=$ strong & 280 & -0.12 & 27.45 & -3.35 & 3.10 \\
\hline & $2=$ moderate & 71 & 1.21 & 0.85 & 1.01 & 1.41 \\
\hline & $3=$ weak & 352 & 1.06 & 0.66 & 0.99 & 1.13 \\
\hline & $4=$ insolvent & 87 & 1.06 & 0.93 & 0.86 & 1.26 \\
\hline & Total & 790 & 0.65 & 16.34 & -0.49 & 1.79 \\
\hline \multirow[t]{5}{*}{ Leverage (LEV) } & $1=$ strong & 280 & 0.87 & 1.65 & 0.67 & 1.06 \\
\hline & $2=$ moderate & 71 & 0.71 & 0.74 & 0.53 & 0.88 \\
\hline & $3=$ weak & 352 & 0.48 & 0.46 & 0.43 & 0.53 \\
\hline & $4=$ insolvent & 87 & 0.50 & 0.41 & 0.41 & 0.59 \\
\hline & Total & 790 & 0.64 & 1.07 & 0.57 & 0.72 \\
\hline \multirow{5}{*}{$\begin{array}{l}\text { Growth of Equity } \\
\text { (GOE) }\end{array}$} & $1=$ strong & 280 & 0.01 & 0.66 & $\begin{array}{l}-0.07 \\
\end{array}$ & 0.09 \\
\hline & $2=$ moderate & 71 & 0.10 & 0.16 & 0.06 & 0.13 \\
\hline & $3=$ weak & 352 & 0.09 & 0.16 & 0.07 & 0.10 \\
\hline & $4=$ insolvent & 87 & 0.08 & 0.11 & 0.06 & 0.10 \\
\hline & Total & 790 & 0.06 & 0.42 & 0.03 & 0.09 \\
\hline \multirow{5}{*}{$\begin{array}{l}\text { Investment } \\
\text { Performance (INP) }\end{array}$} & $1=$ strong & 280 & 2.11 & 19.99 & -0.24 & 4.46 \\
\hline & $2=$ moderate & 71 & 0.32 & 0.66 & 0.16 & 0.48 \\
\hline & $3=$ weak & 352 & 0.33 & 0.82 & 0.24 & 0.41 \\
\hline & $4=$ insolvent & 87 & 0.20 & 0.46 & 0.11 & 0.30 \\
\hline & Total & 790 & 0.94 & 11.93 & 0.11 & 1.78 \\
\hline \multirow{5}{*}{$\begin{array}{l}\text { Operating Expense to } \\
\text { Premium Growth } \\
\text { (OPG) }\end{array}$} & $1=$ strong & 280 & -0.94 & 24.13 & -3.78 & 1.90 \\
\hline & $2=$ moderate & 71 & 0.49 & 0.17 & 0.45 & 0.53 \\
\hline & $3=$ weak & 352 & 0.50 & 0.41 & 0.46 & 0.55 \\
\hline & $4=$ insolvent & 87 & 0.49 & 0.19 & 0.45 & 0.53 \\
\hline & Total & 790 & -0.01 & 14.37 & -1.01 & 0.99 \\
\hline Degree of & $1=$ strong & 280 & 15.88 & 38.29 & 11.37 & 20.38 \\
\hline
\end{tabular}


An Early Warning System on the Propensity of Survival and Failure of Non-life Insurance Firms in

\begin{tabular}{|l|l|r|r|r|r|r|}
\hline \multirow{3}{*}{$\begin{array}{l}\text { Diversification (DOD) } \\
\text { \% }\end{array}$} & $2=$ moderate & 71 & 2.65 & 11.49 & -0.07 & 5.37 \\
\cline { 2 - 7 } & $3=$ weak & 352 & 0.79 & 2.91 & 0.48 & 1.09 \\
\cline { 2 - 7 } & $4=$ insolvent & 87 & 0.20 & 0.41 & 0.11 & 0.29 \\
\cline { 2 - 7 } & Total & 790 & 6.24 & 24.19 & 4.55 & 7.93 \\
\hline \multirow{4}{*}{ Ownership (OWN) } & $1=$ strong & 280 & 0.87 & 0.34 & 0.83 & 0.91 \\
\cline { 2 - 7 } & $2=$ moderate & 71 & 0.89 & 0.32 & 0.81 & 0.96 \\
\cline { 2 - 7 } & $3=$ weak & 352 & 0.91 & 0.28 & 0.88 & 0.94 \\
\cline { 2 - 7 } & $4=$ insolvent & 87 & 0.94 & 0.23 & 0.89 & 0.99 \\
\cline { 2 - 7 } & Total & 790 & 0.90 & 0.30 & 0.88 & 0.92 \\
\hline \multirow{3}{*}{$\begin{array}{l}\text { Capital Compliance } \\
\text { (CCP) }\end{array}$} & 1 = strong & 280 & 1.00 & 0.00 & 1.00 & 1.00 \\
\cline { 2 - 7 } & $2=$ moderate & 71 & 1.00 & 0.00 & 1.00 & 1.00 \\
\cline { 2 - 7 } & $3=$ weak & 352 & 1.00 & 0.05 & 0.99 & 1.00 \\
\cline { 2 - 7 } & $4=$ insolvent & 87 & 0.02 & 0.15 & -0.01 & 0.06 \\
\cline { 2 - 7 } & Total & 790 & 0.89 & 0.31 & 0.87 & 0.91 \\
\hline
\end{tabular}

Table 2. Test of Homogeneity of variances and Robust tests of Means for Non-life insurance companies

\begin{tabular}{|l|r|r|r|r|}
\hline Test of Homogeneity of Variances & & & \\
\hline & Levene Statistic & df1 & df2 & \multicolumn{1}{l|}{ Sig. } \\
\hline Firm Size (FRS) & 16.772 & 3 & 786 & .000 \\
\hline Losses Paid Due to Typhoon (TEX) & 51.104 & 3 & 786 & .000 \\
\hline Losses Paid Due to Flood (FEX) & 47.412 & 3 & 786 & .000 \\
\hline Profitability (PRO) & 5.845 & 3 & 786 & .001 \\
\hline Premium Growth (PRG) & 1.709 & 3 & 786 & .164 \\
\hline Claims Ratio (CLR) & 1.997 & 3 & 786 & .113 \\
\hline Expense Ratio (EXR) & 1.685 & 3 & 786 & .169 \\
\hline Combined Ratio (COR) & 1.884 & 3 & 786 & .131 \\
\hline Leverage (LEV) & 11.256 & 3 & 786 & .000 \\
\hline Growth of Equity (GOE) & 4.667 & 3 & 786 & .003 \\
\hline Investment Performance (INP) & 4.730 & 3 & 786 & .003 \\
\hline Operating Expense to Premium Growth (OPG) & 2.162 & 3 & 786 & .091 \\
\hline Degree of Diversification (DOD) \% & 61.873 & 3 & 786 & .000 \\
\hline Ownership (OWN) & 6.782 & 3 & 786 & .000 \\
\hline Capital Compliance (CCP) & 13.530 & 3 & 786 & .000 \\
\hline
\end{tabular}

\begin{tabular}{|c|c|c|c|c|c|}
\hline \multicolumn{2}{|l|}{ Robust Tests of Equality of Means ${ }^{b}$} & \multirow[b]{2}{*}{ Statistic ${ }^{\mathrm{a}}$} & \multirow[b]{2}{*}{ df1 } & \multirow[b]{2}{*}{ df2 2} & \multirow[b]{2}{*}{ Sig. } \\
\hline & & & & & \\
\hline Firm Size (FRS) & Welch & 82.938 & 3 & 233.663 & .000 \\
\hline Losses Paid Due to Typhoon (TEX) & Welch & 15.397 & 3 & 207.866 & .000 \\
\hline Losses Paid Due to Flood (FEX) & Welch & 14.798 & 3 & 208.362 & .000 \\
\hline $\begin{array}{l}\text { Profitability }(\mathrm{PRO}) \\
\end{array}$ & Welch & .794 & 3 & 228.120 & .498 \\
\hline Premium Growth (PRG) & Welch & .819 & 3 & 245.295 & 484 \\
\hline Claims Ratio (CLR) & Welch & 1.065 & 3 & 256.268 & .364 \\
\hline Expense Ratio (EXR) & Welch & .656 & 3 & 195.809 & .580 \\
\hline Combined Ratio (COR) & Welch & .817 & 3 & 201.901 & 486 \\
\hline Leverage (LEV) & Welch & 6.534 & 3 & 211.605 & .000 \\
\hline Growth of Equity (GOE) & Welch & 1.333 & 3 & 239.859 & .264 \\
\hline Investment Performance (INP) & Welch & 2.075 & 3 & 259.720 & 104 \\
\hline Operating Expense to Premium Growth (OPG) & Welch & 417 & 3 & 317.200 & .741 \\
\hline Degree of Diversification (DOD) \% & Welch & 20.846 & 3 & 245.746 & .000 \\
\hline Ownership (OWN) & Welch & 1.811 & 3 & 219.292 & 146 \\
\hline Capital Compliance (CCP) & Welch & • & . & . & \\
\hline
\end{tabular}


Table 3. Multiple comparisons of survival indicator and determinants of the non-life insurance companies

\begin{tabular}{|c|c|c|c|c|c|}
\hline \multicolumn{6}{|c|}{ Multiple Comparisons (Games-Howell) } \\
\hline Determinants & (I) Survival Indicator & $\begin{array}{l}\text { (J) Survival } \\
\text { Indicator }\end{array}$ & $\begin{array}{c}\text { Mean } \\
\text { Difference (I-J) }\end{array}$ & $\begin{array}{l}\text { Std. } \\
\text { Error }\end{array}$ & Sig. \\
\hline Firm Size (FRS) & $1=$ strong & $2=$ moderate & $.75853^{*}$ & 0.12 & 0.00 \\
\hline Firm Size (FRS) & $1=$ strong & $3=$ weak & $1.21281^{*}$ & 0.08 & 0.00 \\
\hline Firm Size (FRS) & $1=$ strong & 4 = insolvent & $1.10726^{*}$ & 0.09 & 0.00 \\
\hline Firm Size (FRS) & $2=$ moderate & $3=$ weak & $.45428^{*}$ & 0.11 & 0.00 \\
\hline Firm Size (FRS) & $2=$ moderate & 4 = insolvent & $.34873^{*}$ & 0.12 & 0.02 \\
\hline Losses Paid Due to Typhoon (TEX) & $1=$ strong & $3=$ weak & $3.31776^{*}$ & 0.53 & 0.00 \\
\hline Losses Paid Due to Typhoon (TEX) & $2=$ moderate & $3=$ weak & $3.02047^{*}$ & 0.85 & 0.00 \\
\hline Losses Paid Due to Typhoon (TEX) & $4=$ insolvent & $3=$ weak & $2.00808^{*}$ & 0.75 & 0.04 \\
\hline Losses Paid Due to Flood (FEX) & $1=$ strong & $3=$ weak & $3.31487^{*}$ & 0.50 & 0.00 \\
\hline Leverage (LEV) & $1=$ strong & $3=$ weak & $.38610^{*}$ & 0.10 & 0.00 \\
\hline Leverage (LEV) & $1=$ strong & $4=$ insolvent & $.36867^{*}$ & 0.11 & 0.00 \\
\hline Degree of Diversification (DOD) \% & $1=$ strong & $2=$ moderate & $13.22719^{*}$ & 2.66 & 0.00 \\
\hline Degree of Diversification (DOD) \% & $1=$ strong & $3=$ weak & $15.08919^{*}$ & 2.29 & 0.00 \\
\hline Degree of Diversification (DOD) \% & $1=$ strong & 4 = insolvent & $15.67452^{*}$ & 2.29 & 0.00 \\
\hline Degree of Diversification (DOD) \% & $3=$ weak & $4=$ insolvent & $.58533^{*}$ & 0.16 & 0.00 \\
\hline Capital Compliance (CCP) & $1=$ strong & 4 = insolvent & $.97701^{*}$ & 0.02 & 0.00 \\
\hline Capital Compliance (CCP) & $2=$ moderate & $4=$ insolvent & $.97701^{*}$ & 0.02 & 0.00 \\
\hline Capital Compliance (CCP) & $3=$ weak & $4=$ insolvent & $.97417^{*}$ & 0.02 & 0.00 \\
\hline
\end{tabular}

Table 4. Results of logit regression on survival of Non-life insurance companies

\begin{tabular}{|l|r|r|r|r|r|r|r|}
\hline \multicolumn{1}{|c|}{ Variable } & \multicolumn{1}{c|}{ B } & \multicolumn{1}{c|}{ S.E. } & \multicolumn{1}{c|}{ Wald } & \multicolumn{1}{c|}{ d.f. } & \multicolumn{1}{c|}{ Sig. } & r & Exp(B) \\
\hline Constant & -27.475 & 2.316 & 140.741 & 1.000 & 0.000 & \\
\hline Firm Size (FRS) & 1.349 & 0.118 & 131.288 & 1.000 & 0.000 & 0.355 & 3.854 \\
\hline $\begin{array}{l}\text { Losses Paid Due to Typhoon } \\
\text { TEX) }\end{array}$ & -0.036 & 0.015 & 5.652 & 1.000 & 0.017 & 0.060 & 0.965 \\
\hline Leverage (LEV) & 0.291 & 0.128 & 5.186 & 1.000 & 0.023 & 0.056 & 1.338 \\
\hline Growth of Equity (GOE) & -0.951 & 0.439 & 4.693 & 1.000 & 0.030 & -0.051 & 0.386 \\
\hline $\begin{array}{l}\text { Ownership: domestic=1, foreign }= \\
\text { 0 }\end{array}$ & -0.650 & 0.292 & 4.955 & 1.000 & 0.026 & -0.054 & 0.522 \\
\hline dependent: survival & & & & & & \\
\hline
\end{tabular}

Figure 1. Hypothesized Research Model

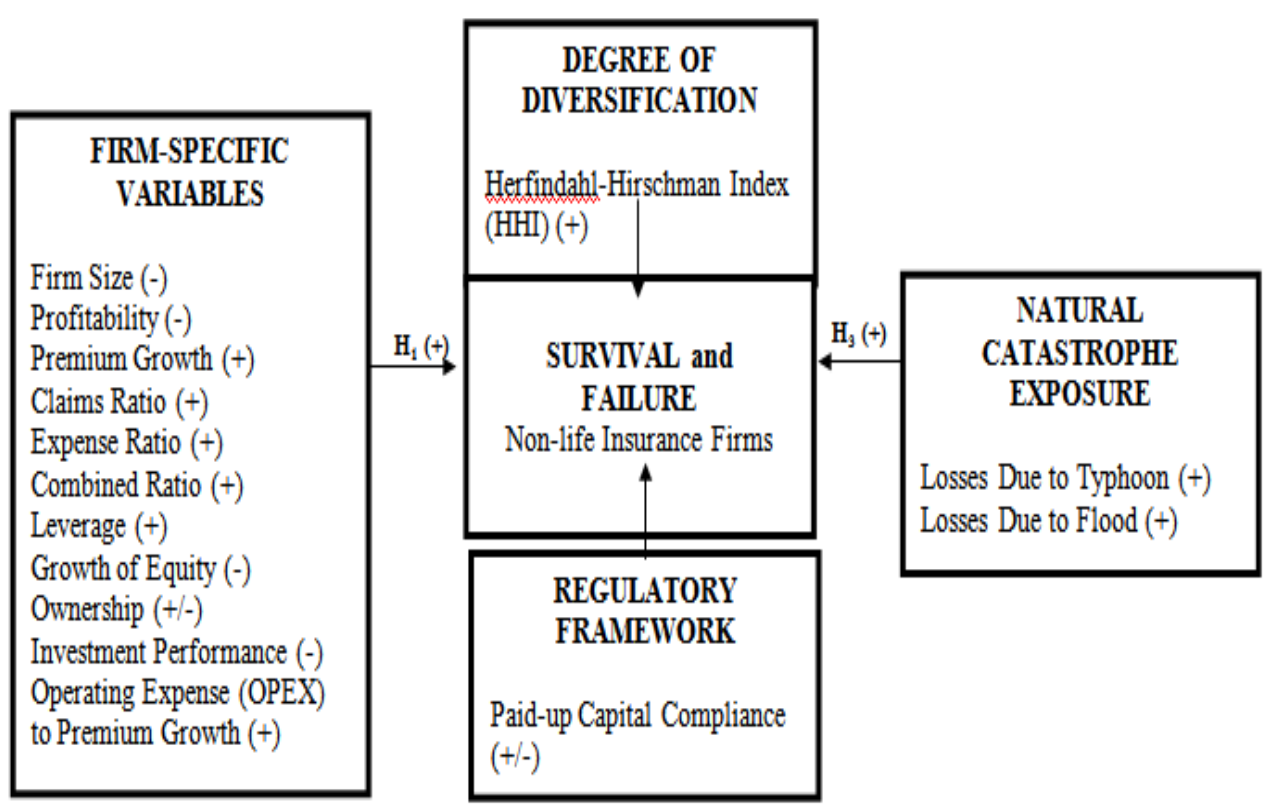

